\title{
Correspondence
}

To the Editors

\section{COVID-19: transmission and breastfeeding}

Sri Lanka Journal of Child Health, 2020; 49(2): 198

DOI: http://dx.doi.org/10.4038/sljch.v49i2.8978

(Key words: COVID-19, transmission, breastfeeding)

COVID-19 is a new emerging respiratory infection caused by SARS-CoV-2, which is a novel coronavirus firstly detected in China ${ }^{1}$. At present, the disease has already spread to more than 50 countries around the world ${ }^{2}$. The patients usually have respiratory problems and death is the unwanted outcome in severe cases $^{3,4}$. COVID-19 can affect any age group. Infants or neonates are also affected ${ }^{3,4}$. The mode through which infants get the infection is very interesting. It is believed that the close contact with the infected mother is the main route of transmission. The interesting consideration is on the possibility that the disease may be transmittable via breast milk. Based on the nanostructure analysis concept, an emerging viral pathogen can be transmitted via breast milk only if the virus is smaller than breast milk gland pore ${ }^{5}$. Molecularly, coronavirus is a large virus and the size of SARS CoV2 is more than $100 \mathrm{~nm}^{6}$ that is larger than a milk gland pore. Therefore, the transmission via breast milk should not occur if there is no pathology of the milk gland. In fact, this same principle of nanostructure consideration can be well applied as the explanation for the lack of vertical transmission of SARS-CoV- $2^{7}$ because the virus is also larger than the placental pores.

\section{References}

1. Hsia W. Emerging new coronavirus infection in Wuhan, China: Situation in early 2020. Case Study and Case Report 2020; 10:8-9.

2. Yasri S, Wiwanitkit V. Editorial: Wuhan coronavirus outbreak and imported case. Advance Tropical Medicine Public Health International 2019; 9:1-2.

3. Wang $\mathrm{D}, \mathrm{Hu} \mathrm{B}, \mathrm{Hu} \mathrm{C}$, Zhu F, Liu X, Zhang J, et al. Clinical characteristics of 138 hospitalized patients with 2019 novel coronavirus-infected pneumonia in Wuhan, China. Journal of the American Medical Association 2020 Feb 7. doi: 10.1001/jama.2020.1585. [Epub ahead of print] https://doi.org/10.1001/jama.2020.1585

PMid: 32031570
4. Chen N, Zhou M, Dong X, Qu J, Gong F, Han Y, et al. Epidemiological and clinical characteristics of 99 cases of 2019 novel coronavirus pneumonia in Wuhan, China: a descriptive study. Lancet 2020; 395(10223): 507-13. https://doi.org/10.1016/S01406736(20)302 11-7

5. Wiwanitkit V. Breastfeeding and HIV infection. International Journal of Nursing Practice 2015; 21: 682.

https://doi.org/10.1111/ijn.12346

PMid: 26503191

6. Sun $\mathrm{P}, \mathrm{Lu} \mathrm{X}, \mathrm{Xu} \mathrm{C}$, Sun W, Pan B. Understanding of COVID-19 based on current evidence. Journal of Medical Virology 2020. doi: 10.1002/jmv.25722. [Epub ahead of print] https://doi.org/10.1002/jmv.25722

PMid: 32096567

7. Li Y, Zhao R, Zheng S, Chen X, Wang J, Sheng $X$, et al. Lack of vertical transmission of severe acute respiratory syndrome coronavirus 2, China. Emerging Infectious Diseases 2020 Jun 17; 26(6). doi: 10.3201/eid2606.200287. [Epub ahead of print] https://doi.org/10.3201/eid2606.200287

\footnotetext{
*Beuy Joob ${ }^{1}$, Viroj Wiwanitkit ${ }^{2}$

${ }^{1}$ Sanitation 1 Medical Academic Centre, Bangkok, Thailand

${ }^{2}$ Honorary Professor, Dr. DY Patil University,

Pune, India and Visiting Professor, Hainan

Medical University, Haikou, China

*Correspondence: Email: beuyjoob@hotmail.com

iD. orcid.org/ 0000-0002-5281-0369
} 